\title{
29. IMPLICATIONS OF DEEP SEA DRILLING, SITES 186 AND 187 ON ISLAND ARC STRUCTURE
}

\author{
John A. Grow ${ }^{1}$, Marine Physical Laboratory, Scripps Institution of Oceanography, La Jolla, California
}

\section{INTRODUCTION}

Pacific island arcs typically have a sediment-filled trough or terrace between the trench and island ridge which is separated from the trench by a mid-slope basement high (Karig, 1970). Such a terrace is extremely well developed south of the central Aleutian Arc and has been referred to as the Aleutian Terrace (Nichols and Perry, 1966). Reflection records over the Atka Basin (Figure 1) portion of the Aleutian Terrace show an asymmetric trough with over 2 $\mathrm{km}$ of acoustically visible sediments in the north central part of the terrace. A sonobuoy refraction profile near the center of Atka Basin suggests a thick sediment pile (5-8 km) over an oceanic-like crust $(6.4 \mathrm{~km} / \mathrm{sec} ;$ Grow, 1972). The structure of the mid-slope basement high which separates such sediment troughs and their adjacent trenches is poorly understood; and Sites 186 and 187 were specifically drilled on the southern edge of the Aleutian Terrace in order to sample the material which forms this basement high.

\section{FOLDED SEDIMENTS ON THE SOUTHERN EDGE OF THE ALEUTIAN TERRACE}

The reflection profile used to select Sites 186 and 187 (obtained by E.L. Hamilton on U.S.N.S. Bartlett) suggested the presence of folded or diapir-like structures near the southern edge of the Aleutian Terrace. The presite survey conducted by the D/V Glomar Challenger obtained five other short profiles within approximately $5 \mathrm{~km}$ of Hamilton's profile which confirm the presence of lineated anticlinal folds. Figures 2 and 3 show the ship tracks and reflection records for both Hamilton's and the D/V Glomar Challenger's profiles. The deeper layers on the north ends of profiles $\mathrm{AB}, \mathrm{EF}$, and IG dip northward at an average of $2^{\circ}-5^{\circ}$ with at least two anticlinal folds superimposed on this overall northward dip. Anticlinal folds $\mathrm{Y}$ and $\mathrm{Z}$ have wavelengths of about 3-5 km (Figure 2) and amplitudes of 100-200 meters (superimposed on the mean northerly dip, Figure 3). Internal structure within the deeper part of ridge $\mathrm{X}$ is not observed except for slight indications of folded sediments in profile HG, and a well-defined "acoustic basement" appears to be present beneath the top 150-200 meters of layered sediments on profile EF. The layered sediments coming south from anticline $\mathrm{Y}$ appear to intersect the acoustic basement on the north side of ridge $\mathrm{X}$ in a discordant manner. The acoustic basement on the north flank of ridge $\mathrm{X}$ dips at an angle of $15^{\circ}-20^{\circ}$ in profile EF.

\footnotetext{
${ }^{1}$ Current Address: Dept. Earth and Planetary Sciences, Massachusetts Institute of Technology, Cambridge, Massachusetts.
}

Evidence for folded sediments in Pacific trench arc systems has been extremely rare (Scholl et al., 1968). Reflection profiles over Hawley Ridge (Figure 1) have revealed a broad anticlinal arch without shorter wavelength folds (Grow, 1972). Near-bottom geophysical measurements over the Aleutian Trench south of Atka Basin (Grow, 1972) show that undeformed trench sediments terminate abruptly against the north slope which has its steepest slopes $\left(30^{\circ}-35^{\circ}\right)$ within the first $0.5-1.0 \mathrm{~km}$ north of the flat, undeformed trench sediments. Acoustically opaque (unresolvable) slopes are found between the trench and the southern edge of the Aleutian Terrace, with their steepness decreasing northward. Gravity and near-bottom magnetic data indicate, however, that low density $(2.2-2.4 \mathrm{~g} / \mathrm{cc})$ and low magnetization materials underlie this acoustically unresolvable north slope (Grow, 1972). No evidence for small-scale tensional faulting was observed by the nearbottom geophysical system on the north slope, and complex thrusting and/or very short wavelength folding $(<$ $1 \mathrm{~km}$ ) is probably responsible for the acoustically unresolvable character of the north slope. The broader anticlinal folds seen in Figure 3 appear to be the northern limit of the near-surface compressional zone which separates the Pacific crust and the Aleutian Arc. The zone of folded sediments on the southern edge of the Aleutian Terrace appears to be one of the few places in trench-arc systems where the folding is of broad enough wavelength and small enough amplitude to be resolved by a surface reflection system.

\section{ACOUSTIC BASEMENT DRILLED AT SITES 186 AND 187}

Deep Sea Drilling Site 186 reached a subbottom depth of 930 meters in Pliocene terrace sediments. The lower 200 to 300 meters may have been in the acoustic basement (see profile EF, Figure 3); inclined bedding was recovered in some of the cores. After drilling through 170 meters of Plio-Pleistocene (?) sediments, Site 187 drilled another 200 meters into the acoustic basement (profile EF, Figure 3), which was composed of upper Miocene sediments. Diatomaceous silty clay, rich in volcanic sand and pumice, was the dominant lithology throughout the section at Sites 186 and 187 (see Chapters 5 and 6). Velocities and densities both increased with depth up to about $1.8-2.0 \mathrm{~g} / \mathrm{cc}$ and 2.0 $\mathrm{km} / \mathrm{sec}$. Although there is approximately 700 meters of structural relief between the Pliocene at the base at Site 186 and the upper Miocene of the top of ridge $\mathrm{X}$ at Site 187 , the vertical exaggeration in profile EF $(12 X)$ makes this appear more significant than would a profile with no exaggeration. Therefore, even though some type of "acoustic basement" appears to be present beneath the southern edge of the Aleutian Terrace, both deep-sea drilling sites indicate that it is composed of deformed terrace sediments. 


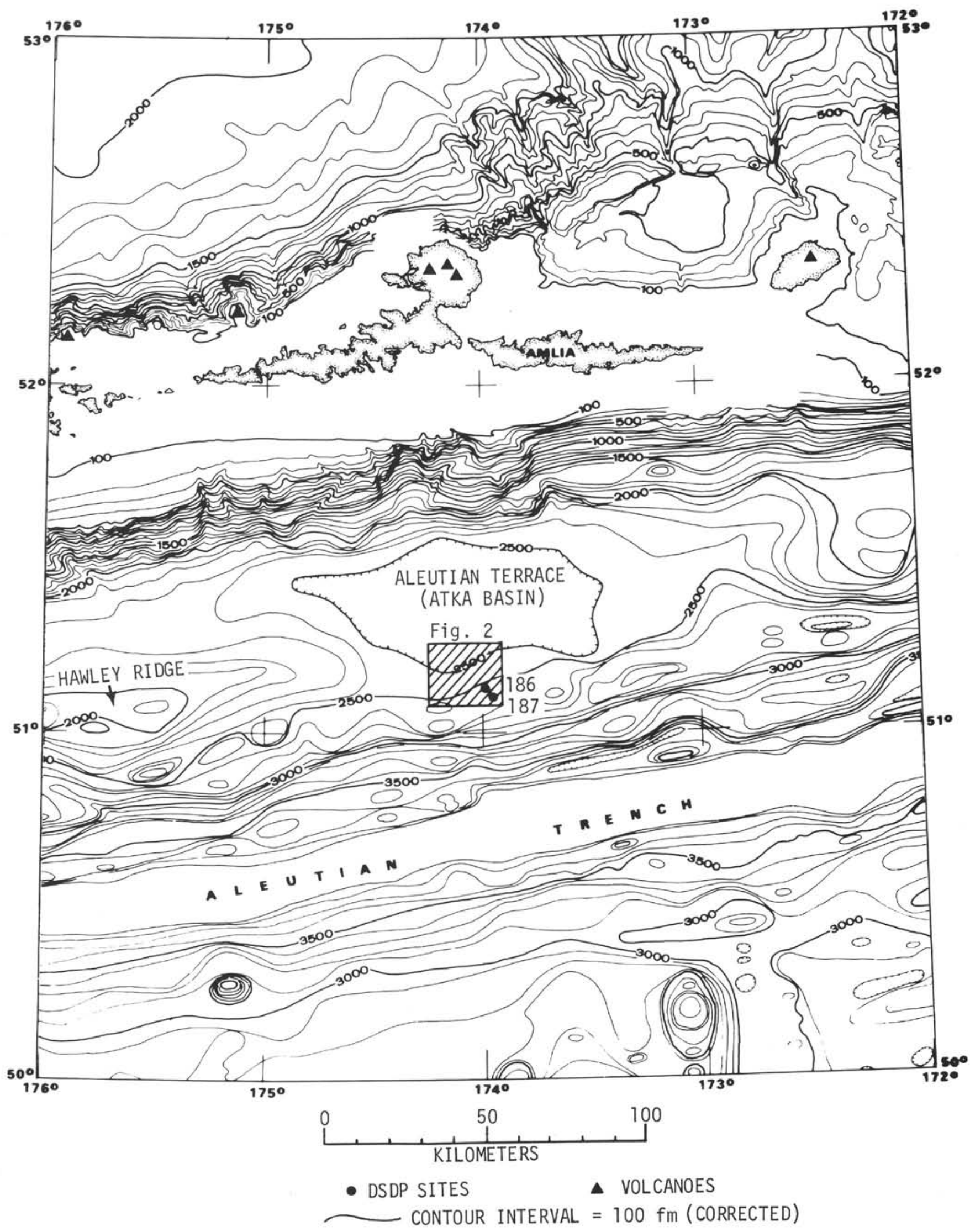

Figure 1. Central Aleutian bathymetry modified from Nichols and Perry (1866) showing position of Sites 186 and 187 and track chart shown in Figure 2. 


\section{CONCLUSIONS}

The five closely spaced reflection profiles near Sites 186 and 187 clearly demonstrate the presence of gently folded anticlinal ridges which parallel the Aleutian Trench and Terrace. These folds probably reflect the compressional stresses between the Aleutian arc and the Pacific lithospheric plate. The acoustic basement penetrated at Sites 186 and 187 proved to be deformed upper Miocene and Pliocene sediments. Free air gravity anomalies are between -150 and -200 mgals over the entire Aleutian Trench and Terrace, and they indicate that low-density materials $(2.2-2.4 \mathrm{~g} / \mathrm{cc})$ are probably about $5 \mathrm{~km}$ thick beneath Sites 186 and 187 (Grow, 1972). Therefore, the mid-slope basement high which separates the Aleutian Trench and Terrace appears to be an uplifted sedimentary arch composed of compressively deformed terrace sediments. More deformed trench sediments (complexly folded and/or thrusted ?) are probably present on the lower part of the north trench slope and at depth beneath the mid-slope basement high, but these are acoustically unresolvable.

Some of the western Pacific island arcs such as the Bonin and Marianas have mid-slope basement highs with much more positive gravity anomalies over them than the southern edge of the Aleutian Terrace (Hayes and Ewing, 1970). These may reflect the incorporation of more high-density igneous rocks in the offscrapings from the Pacific plate or the uplifting of the leading edge of the island arc crust. Island arcs such as the Antilles (Bowin, in press) and the Indonesian arcs (Vening Meinesz, 1954) have their minimum gravity anomalies well in over the inner trench slope and sediment terrace, and their mid-slope topographic highs appear to be underlain by thick accumulations of low-density deformed sediments like the central Aleutians.

\section{ACKNOWLEDGMENTS}

E. L. Hamilton's excellent reflection profile over the Aleutian Terrace led to selection of deep-sea drilling Sites 186 and 187. I sincerely appreciate his allowing me to incorporate his profile along with the D/V Glomar Challenger reflection profiles shown in Figure 3. Discussions with D. W. Scholl, R. J. Stewart, and M. S. Marlow have helped develop some of the ideas presented in this paper. This work has been supported by the Office. of Naval Research and the National Science Foundation.

\section{REFERENCES}

Bowin, C., in press. Does the lithosphere really sink at sites of underthrusting? Science.

Grow, J.A., 1972. A geophysical study of the central Aleutian Arc. PhD. Thesis, University of California, San Diego. $132 \mathrm{p}$.

Hayes, D.E. and Ewing, M., 1970. Pacific boundary structure. In The Sea, Maxwell, A.E., (ed.), Vol. 4, Part II, New York. (Wiley-Interscience), 29.

Karig, D.E., 1970. Ridges and basins of the TongaKermadec Island arc system. J. Geophys. Res.75, 239.

Nichols, H. and Perry, R.B., 1966. Bathymetry of the Aleutian Arc, Alaska. Environ. Sci. Serv. Admin. Mono 3 .

Scholl, D. W., von Huene, R. and Ridlon, J. B., 1968. Spreading of the ocean floor: Undeformed sediments of the Peru-Chile Trench. Science. 159, 869.

Vening Meinesz, F.A., 1954. Indonesian Archipelago - a geophysical study. Bull. Geol. Soc. Am. 65, 143. 


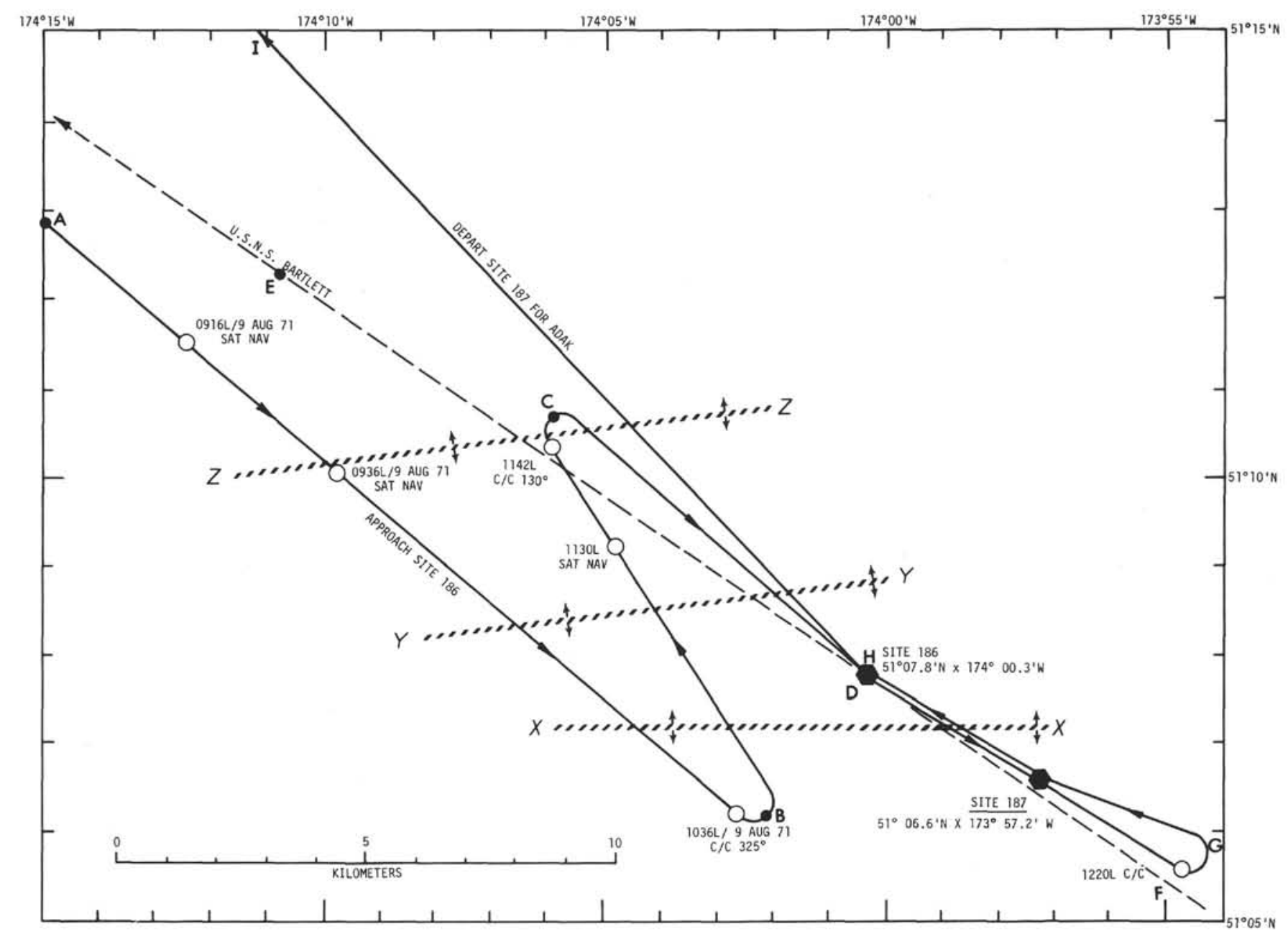

Figure 2. Track charts of $D / V$ Glomar Challenger and U.S.N.S. Bartlett which were used for the reflection profiles in Figure 3. The traces of the three anticlinal ridges $(X, Y$, and $Z)$ shown in Figure 3 are also plotted. 


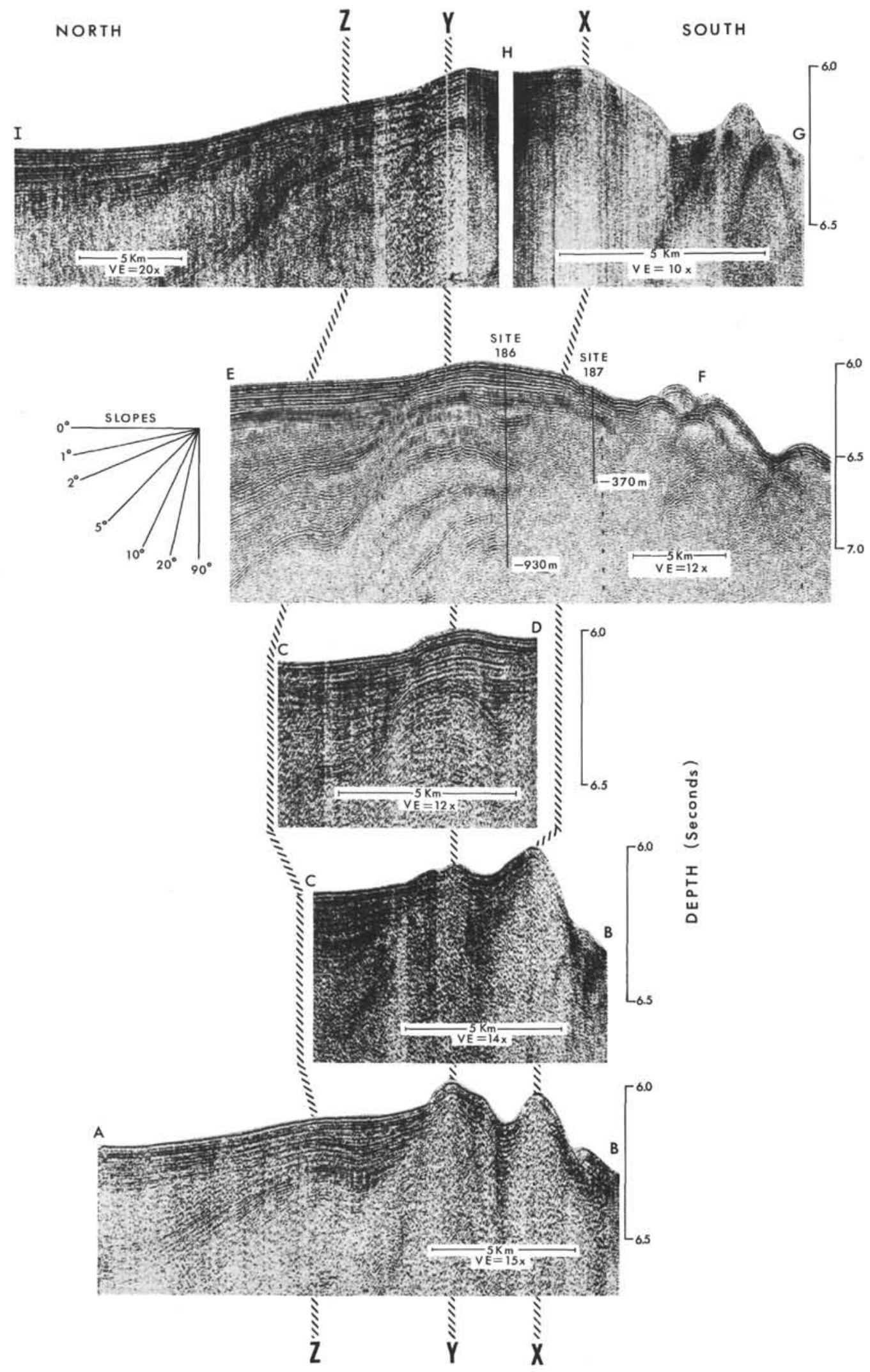

Figure 3. Reflection profiles over the southern edge of Aleutian Terrace obtained by E. L. Hamilton (EF) on the U.S.N.S. Bartlett and the $D / V$ Glomar Challenger $(A B, B C, C E$, and $I G)$. Anticlinal folds $Y$ and $Z$ have wavelengths of $304 \mathrm{~km} / \mathrm{see}$ Fig. 2) with amplitudes of 100-200 meters relative to the regional northerly dip of $2^{\circ}-5^{\circ}$ seen in the deeper terrace sediments. Acoustic basement drilled at bottom of Sites 186 and 187 was composed of deformed sediment. 